\title{
PENGARUH LINGKUNGAN KERJA DAN MOTIVASI TERHADAP KINERJA KARYAWAN PADA PT. NAGA MAS INTIPRATAMA TANGERANG
}

\author{
Jeni Andriani ${ }^{1}$, Lili Sularmi ${ }^{2}$, Ninik Anggraini ${ }^{3}$ \\ Fakultas Ekonomi, Universitas Pamulang \\ Email: dosen00436@unpam.ac.id1.dosen02042@unpam.ac.id². \\ dosen00976@unpam.ac.id ${ }^{3}$
}

\begin{abstract}
Purpose. To determine the effect of work environment and motivation on employee performance at PT. Naga Mas Intipratama Tangerang.

Methods. The method used in this research is quantitative method, namely through the approach, data collection and analysis using statistics. The data used through observation techniques, questionnaires (questionnaire as many as 60 respondents) and literature. The analysis method used in this research is validity test, reliability test, normality test, multicollinearity test, autocorrelation test, heteroscedasticity test, multiple linear regression test, correlation coefficient test, determination test and significant test ( $t$ test and f test).
\end{abstract}

Findings. The significant value of $F$ is $0.000(<0.05)$, it can be concluded that the hypothesis is accepted, meaning that the work environment and motivation variables have a positive and significant effect together on employee performance. The $R$ value (correlation coefficient) is 0.859. So it can be interpreted that the relationship between work environment variables and motivation on employee performance is a very strong correlation. The coefficient of determination (R) was obtained at $78.3 \%$. While the rest of $26.2 \%$ is influenced by other factors which are not discussed in this study. It is known that the significant value for the effect of X1 (work environment) on $Y$ (employee performance) is $0.000<0.05$ and the $t$ value is 11.163>1.672, so it can be concluded that Ha_1 is accepted, which means that there is an effect of X1 on $Y$. It is known that the significant value for the effect of X2 (motivation) to $Y$ (employee performance) is $0.000<0.05$ and the $t$ value is $6.145>1.672$, so it can be concluded that Ha_2 is accepted, which means that there is an influence of X2 on Y.It is known that the significant value for the effect of X1 (work environment) on $Y$ (employee performance) ) is $0.000<0.05$ and the $t$ value is $11.163>1.672$ and it is known that the significant value for the influence of $X 2$ (motivation) on $Y$ (employee performance) is 0.000 $<0.05$ and the $t$ value is $6.145>1.672$, so it can be concluded that Ha_1 and Ha_2 are accepted meaningfully. there is the influence of X1 and X2 on $Y$ together. This means that the Work Environment and Motivation have a sufficient role in improving Employee Performance at PT. Naga Mas Intiprtam.

Implication. The company should pay more attention to work facilities and equipment so that employees can easily complete work with the available facilities. The company should be more effective in motivating employees to develop their abilities.

Keywords. Work Environment, Motivation, Employee Performance. 


\begin{abstract}
ABSTRAK
Tujuan. Untuk mengetahui pengaruh lingkungan kerja dan motivasi terhadap kinerja karyawan pada PT. Naga Mas Intipratama Tangerang.

Metode. Metode yang digunakan pada penelitian ini yaitu metode kuantitatif, yaitu melalui pendekatan, pengumpulan data dan analisa menggunakan statistic. Data yang digunakan melalui teknik observasi, angket (kuesioner sebanyak 60 responden) dan kepustakaan. Metode analisa yang digunakan dalam penelitian ini adalah uji validitas, uji realibilitas, uji normalitas, uji Multikolinearitas, uji autokorelasi, uji Heteroskedastisitas, uji regresi linear berganda, uji koefisien korelasi, uji determinasi dan uji signifikan (uji t dan uji f).
\end{abstract}

Hasil. Nilai signifikan F sebesar $0.000(<0.05)$ maka dapat disimpulkan bahwa hipotesis diterima, artinya variabel lingkungan kerja dan motivasi berpengaruh positif dan signifikan secara bersama-sama terhadap kinerja karyawan. Nilai R (koefisien korelasi) adalah 0,859. Maka dapat diartikan drajat hubungan antara variabel lingkungan kerja dan motivasi terhadap kinerja karyawan merupakan korelasi sangat kuat. Nilai koefisien determinasi (R) tersebut diperoleh sebesar 78,3\%. Sedangkan selebihnya sebesar $26,2 \%$ dipengaruhi oleh factor lain yang tidak dibahas dalam penelitian ini. Diketahui nilai signifikan untuk pengaruh X1 (lingkungan kerja) terhadap Y (kinerja karyawan) adalah sebesar $0.000<0.05$ dan nilai t hitung 11,163 > 1,672, sehingga dapat disimpulkan bahwa Ha_1 diterima yang berarti terdapat pengaruh X1 terhadap Y. Diketahu nilai signifikan untuk pengaruh X2 (motivasi) terhadap Y (kinerja karyawan) adalah sebesar $0.000<0.05$ dan nilai $t$ hitung 6,145 >1,672, sehingga dapat disimpulkan bahwa Ha_2 diterima yang berarti terdapat pengaruh X2 terhadap Y. Diketahui nilai signifikan untuk pengaruh X1 (lingkungan kerja) terhadap Y (kinerja karyawan) adalah sebesar $0.000<0.05$ dan nilai $t$ hitung 11,163 > 1,672 dan Diketahu nilai signifikan untuk pengaruh X2 (motivasi) terhadap Y (kinerja karyawan) adalah sebesar 0.000<0.05 dan nilai t hitung 6,145 > 1,672, sehingga dapat disimpulkan Ha_1 dan Ha_2 diterima berarti terdapat pengaruh X1 dan X2 terhadap Y secara bersama. Hal ini berarti Lingkungan Kerja dan Motivasi cukup memiliki peranan dalam meningkatkan Kinerja Karyawan pada PT. Naga Mas Intiprtama.

Implikasi. Pihak perusahaan agar dapat lebih memperhatikan fasilitas dan perlengkapan kerja agar karyawan dapat dengan mudah menyelesaikan pekerjaan dengan fasilitas yang tersedia. Pihak perusahaan agar dapat lebih efektif lagi dalam memberikan motivasi pada karyawan untuk mengembangkan kemampuannya.

Kata Kunci. Lingkungan Kerja, Motivasi, Kinerja Karyawan.

\title{
1. Pendahuluan
}

PT. Naga Mas Intipratama beralamat di Jl. Padat Karya No 68 Curug Kulon Kec. Curug Kab. Tangerang, 15810, Banten. PT. Naga Mas Intipratama merupakan salah satu perusahaan yang bergerak di bidang manufacture fasteners (bolt and screw)/baut, yang berdiri pada tahun 2014 dan mulai beroperasi pada bulan Maret 2014. Hingga saat ini PT. Naga Mas Intipratama mulai berkembang dari banyaknya customer, sehingga penambahan kapasitas mesin yang menghasilkan banyaknya hasil produksi.

Dari observasi ke HRD PT. Naga Mas Intipratama Tangerang permasalahan yang terjadi adalah lingkungan kerja karyawan belum sepenuhnya terpenuhi oleh perusahaan dapat dilihat yaitu lingkungan kurang memadai, suara bising yang disebabkan mesin produksi, fasilitas dan perlengkapan kerja seperti komputer dan printer yang kurang memadai. Berikut data sarana prasarana PT. Naga Mas Intipratama Tangerang. 
Tabel 1. Sarana Prasana Kerja Karyawan PT. Naga Mas Intipratama Tangerang Tahun 2019

\begin{tabular}{|c|l|c|c|c|}
\hline No. & \multicolumn{1}{|c|}{ Sarana } & $\begin{array}{c}\text { Yang } \\
\text { Diharapkan }\end{array}$ & Realisasi & Kurangnya \\
\hline 1 & Komputer & 22 & 19 & 3 \\
\hline 2 & Mesin fotocopy & 5 & 2 & 3 \\
\hline 3 & Printer & 10 & 8 & 2 \\
\hline 4 & $\begin{array}{l}\text { Liquid Crsytal Display } \\
\text { (LCD)Projector }\end{array}$ & 3 & 1 & 2 \\
\hline 5 & Lemari Besi & 5 & 3 & 2 \\
\hline 6 & Lemari Buku & 7 & 6 & 1 \\
\hline 7 & Lemari File & 5 & 3 & 2 \\
\hline 8 & Stempel & 8 & 5 & 3 \\
\hline
\end{tabular}

Sumber : PT. Naga Mas Intipratama, 2019

Berdasarkan tabel 1. dapat dilihat bahawa lingkungan kerja karyawan di PT. Naga Mas Intipratama Tangerang masih belum optimal mulai dari penyediaan sarana yang masih kurang seperti komputer terdapat 19 unit dimana hal ini dirasakan kurang, printer tersedia 8 unit, LCD projector sebanyak 1 unit, lemari besi tersedia 3 unit, lemari buku tersedia 6 unit, lemari file tersedia 3 unit, stempel tersedia 5 unit, dan 2 unit mesin fotocopy yang masih digunakan secara bergilir.

Adapun permasalahan dalam motivasi adalah karyawan kurang termotivasi untuk lebih cepat menyelesaikan pekerjaan. Hubungan sosial antara karyawan kurang terjalin dengan baik dikarenakan kurangnya komunikasi.Pimpinan perusahaan kurang memberikan apresiasi terhadap pekerjaan karyawan dan jarangnya pemberian penghargaan bagi prestasi kerja karyawan seperti kurangnya promosi jabatan, kurang diberikannya aktualisasi diri kepada karyawan dimana karyawan tidak diberikan kesempatan diri untuk mengembangkan kemampuan yang dimiliki membuat motivasi kerja menurun sehingga mempengaruhi kinerja karyawan mengakibatkan karyawan bekerja asal-asalan dan tidak tepat waktu dalam menyeselasikan pekerjaan.

Tabel 2. Penilaian Kinerja Karyawan PT. Naga Mas Intipratama Tangerang 2019

\begin{tabular}{|c|c|c|c|c|c|c|}
\hline \multirow[b]{2}{*}{ No } & \multirow[b]{2}{*}{ Komponen } & \multirow[b]{2}{*}{ Total } & \multicolumn{3}{|c|}{ Jumlah Pencapaian Penilaian } & \multirow[b]{2}{*}{ Kriteria } \\
\hline & & & $\begin{array}{c}\text { Mencapai } \\
\text { Target }\end{array}$ & $\begin{array}{c}\text { Tidak } \\
\text { Mencapai } \\
\text { Target }\end{array}$ & $\begin{array}{c}\text { Presentase } \\
\text { (\%) }\end{array}$ & \\
\hline 1 & Kehadiran & 60 & 41 & 19 & $68 \%$ & Cukup \\
\hline 2 & $\begin{array}{l}\text { Kepatuhan } \\
\text { peraturan }\end{array}$ & 60 & 35 & 25 & $58 \%$ & Sedang \\
\hline 3 & Kepemimpinan & 60 & 35 & 25 & $58 \%$ & Sedang \\
\hline 4 & Integritas & 60 & 29 & 31 & $48 \%$ & Buruk \\
\hline 5 & Kerjasama & 60 & 33 & 27 & $55 \%$ & Sedang \\
\hline 6 & $\begin{array}{c}\text { Orientasi } \\
\text { pelayanan }\end{array}$ & 60 & 38 & 22 & $63 \%$ & Cukup \\
\hline 7 & Kedisiplinan & 60 & 25 & 35 & $42 \%$ & Buruk \\
\hline 8 & $\begin{array}{l}\text { Penyelesaian } \\
\text { pekerjaan }\end{array}$ & 60 & 25 & 35 & $42 \%$ & Buruk \\
\hline & Rata-rata & 480 & 33 & 28 & $54 \%$ & Sedang \\
\hline
\end{tabular}

Kriteria (\%) : 1-50 = Buruk, 51-60 = Sedang, 61-70 = Cukup, 71-80 = Baik, 81-99 = Sangat Baik Sumber : PT. Naga Mas Intipratama, 2019 
Berdasarkan tabel diatas terlihat kinerja PT. Naga Mas Intipratama Tangerang kurang maksimal. Hal ini bisa dilihat dari data diatas pencapaian target penyelesaian pekerejaan menunjukan angka $42 \%$ hanya 25 yang mampu mencapai target dan 35 tidak mencapai target yang mengakibatkan hasil pencapaian kerja tidak sesuai dengan target yang ditetapkan dan tentunya akan menghambat pencapaian tujuan perusahaan.

Kinerja sangat penting dalam pencapaian target bagi semua perusahaan, karena target menjadi tolak ukur perusahaan dalam melihat kinerja karyawan apakah sudah sesuai dengan tujuan perusahaan atau belum tercapai. Maka dari itu untuk meningkatkan kinerja perlu perhatian khusus untuk baik dari perusahaan maupun dari masing-masing individu karyawan tersebut. Penulis melihat terdapat beberapa hasil data lingkungan kerja yang berdampak pada kinerja karyawan berdasarkan uraian dari permasalahan diatas maka penulis tertarik melakukan penelitian berjudul "Pengaruh Lingkungan Kerja Dan Motivasi Terhadap Kinerja Karyawan Pada PT. Naga Mas Intipratama Tangerang".

\section{Kajian Pustaka dan Hipotesis}

Lingkungan Kerja. Menurut Danang Sunyoto (2015:43) "lingkungan kerja merupakan bagian komponen yang sangat penting ketika karyawan melakukan aktivitas bekerja dengan memperhatikan lingkungan kerja yang baik atau menciptakan kondisi kerja yang mampu memberi motivasi akan membawa pengaruh terhadap kegairahan atau semangat karyawan dalam bekerja". Menurut Mangkunegara (2013:17) "lingkungan kerja yang dimaksud antara lain, uraian jabatan yang jelas, target kerja yang menantang, pola komunikasi yang efektif, iklim kerja dan fasilitas kerja yang relative memadai". Menurut Nitisemito (2013:97) "lingkungan kerja adalah segala sesuatu yang ada disekitar karyawan dan dapat mempengaruhi dalam menjalankan tugas yang diemban kepadanya".

Motivasi. Menurut Wibowo (2016:323) "motivasi merupakan serangkaian proses yang membangkitkan (arouse), mengarahkan (direct), dan menjaga (maintain) perilaku manusia menuju pada pencapaian tujuan. Menurut Handoko (2013:13) "motivasi merupakan keadaan dalam pribadi seseorang yang mendorong keingingan individu untuk melakukan kegiatankegiatan tertentu guna untuk mencapai tujuan". Lebih lanjut lagi menekankan bahwa motivasi yang ada pada diri seseorang merupakan kekuatan pendorong yang akan mewujudkan suatu prilaku guna untuk mencapai tujuan kepuasan dirinya.

Kinerja Karyawan. Menurut Mangkunegara (2015:67) "kinerja adalah hasil kerja secara kualitas dan kuantitas yang dicapai oleh seorang pegawai dalam melaksanakan tugasnya sesuai dengan tanggung jawab yang diberikan". Menurut Rivai (2013:604) "kinerja merupakan suatu istilah secara umum yang digunakan sebagai atau seluruh tindakan atau aktivitas dari suatu organisasi pada suatu periode dengan suatu referensi pada sejumlah standar seperti biaya masa lalu yang diproyeksikan dengan dasar efesiensi, pertanggung jawaban atau akuntabilitas manajemen dan sebagainya".

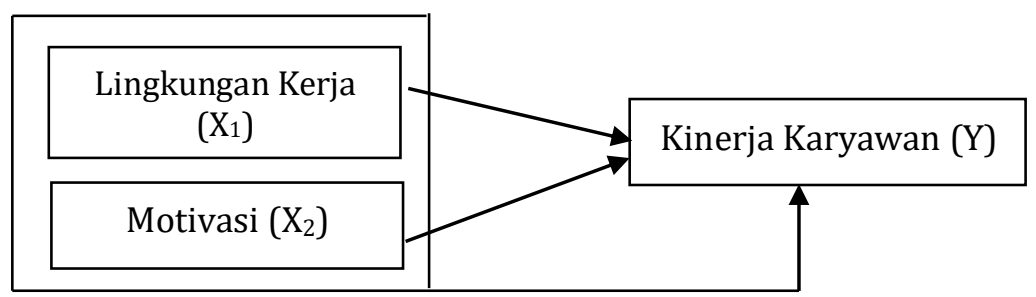

Gambar 1. Model Penelitian 


\section{Hipotesis}

Ho1: Diduga tidak terdapat pengaruh positif dan signifikan lingkungan kerja terhadap kinerja karyawan pada PT. Naga Mas Intipratama Tangerang

Ha1: Diduga terdapat pengaruh positif dan signifikan lingkungan kerja terhadap kinerja karyawan pada PT. Naga Mas Intipratama Tangerang

Ho2: Diduga tidak terdapat pengaruh positif dan signifikan motivasi terhadap kinerja karyawan pada PT. Naga Mas Intipratama Tangerang

Ha2 : Diduga terdapat pengaruh positif dan signifikan motivasi terhadap kinerja karyawan pada PT. Naga Mas Intipratama Tangerang

Ho3 : Diduga tidak terdapat pengaruh positif dan signifikan lingkungan kerja dan motivasi terhadap kinerja karyawan pada PT. Naga Mas Intipratama Tangerang.

Ha3 : Diduga terdapat pengaruh positif dan signifikan lingkungan kerja dan motivasi terhadap kinerja karyawan pada PT. Naga Mas Intipratama Tangerang

\section{Metode Penelitian}

Jenis penelitian dalam penelitian ini yaitu penelitian kuantitatif. Sedangkan metode yang digunakan dalam penelitian ini mengunakan metode asosiatif, menurut Sugiyono (2015:44) yaitu "penelitian yang bertujuan untuk mengetahui pengaruh hubungan antara dua variabel lebih". Penelitian asosiatif mempunyai tingkatan yang lebih tinggi bila dibandingkan dengan deskriptif dan komparatif, lebih lanjut Sugiyono (2015:44) menejelaskan dengan penelitian asosiatif maka dibangun suatu teori yang berfungsi untuk menjelaskan, meramalkan dan mengontrol suatu gejala".

Populasi dalam penelitian ini adalah seluruh karyawan yang bekerja pada PT. Naga Mas Intipratama Tangerang sebanyak 60 karyawan. Sampel dalam penelitian ini berjumalah 60 responden dengan menggunakan sampel jenuh atau biasa disebut sensus. Menurut Sugiyono (2012:68) sampling jenuh adalah teknik penentuan sampel bila semua anggota populasi digunakan sebagai sampel.

Teknik analisis data dengan menggunakan Uji validitas, uji reliabilitas, uji normalitas, uji multikolinearitas, uji heteroskedastisitas, uji regresi linier berganda, serta uji hipotesis.

Tabel 3. Operasional Variabel Penelitian

\begin{tabular}{|c|c|c|c|}
\hline Variabel & Indikator & $\begin{array}{c}\text { Nomor } \\
\text { Kuesioner }\end{array}$ & Skala \\
\hline \multirow{5}{*}{$\begin{array}{c}\text { Lingkungan Kerja } \\
\left(\mathrm{X}_{1}\right)\end{array}$} & 1. Tata ruang & 1,2 & \multirow[t]{5}{*}{ Likert } \\
\hline & 2. Suara bising & 3,4 & \\
\hline & 3. Penggunaan warna & 5,6 & \\
\hline & 4. Fasilitas dan perlengkapan & 7,8 & \\
\hline & 5. Keamanan kerja & 9,10 & \\
\hline \multirow[t]{5}{*}{ Motivasi $\left(\mathrm{X}_{2}\right)$} & 1. Kebutuhan fisiologis & 1,2 & \multirow[t]{5}{*}{ Likert } \\
\hline & 2. Kebutuhan rasa aman & 3,4 & \\
\hline & 3. Kebutuhan hubungan sosial & 5,6 & \\
\hline & 4.Kebutuhan pengakuan & 7,8 & \\
\hline & 5.Kebutuhan aktualisasi diri & 9,10 & \\
\hline \multirow{4}{*}{$\begin{array}{c}\text { Kinerja Karyawan } \\
\text { (Y) }\end{array}$} & 1. Kualitas & $1,2,3$ & \multirow[t]{4}{*}{ Likert } \\
\hline & 2. Kuantitas & 4,5 & \\
\hline & 3. Pelaksanaan Tugas & 6,7 & \\
\hline & 4. Tanggung Jawab & $8,9,10$ & \\
\hline
\end{tabular}




\section{Hasil Penelitian dan Pembahasan Uji Validitas}

Tabel 4. Hasil Uji Validitas

\begin{tabular}{|c|c|c|c|c|}
\hline No & Pernyataan & $\boldsymbol{r}_{\text {hitung }}$ & $r_{\text {tabel }}$ & $\begin{array}{c}\text { Keterangan } \\
\text { Butir }\end{array}$ \\
\hline \multicolumn{5}{|c|}{ Lingkungan Kerja } \\
\hline 1 & Butir Pernyataan 1 & 0,731 & 0,211 & Valid \\
\hline 2 & Butir Pernyataan 2 & 0,695 & 0,211 & Valid \\
\hline 3 & Butir Pernyataan 3 & 0,603 & 0,211 & Valid \\
\hline 4 & Butir Pernyataan 4 & 0,557 & 0,211 & Valid \\
\hline 5 & Butir Pernyataan 5 & 0,243 & 0,211 & Valid \\
\hline 6 & Butir Pernyataan 6 & 0,282 & 0,211 & Valid \\
\hline 7 & Butir Pernyataan 7 & 0,630 & 0,211 & Valid \\
\hline 8 & Butir Pernyataan 8 & 0,434 & 0,211 & Valid \\
\hline 9 & Butir Pernyataan 9 & 0,492 & 0,211 & Valid \\
\hline 10 & Butir Pernyataan 10 & 0,218 & 0,211 & Valid \\
\hline \multicolumn{5}{|c|}{ Motivasi } \\
\hline 1 & Butir Pernyataan 1 & 0,553 & 0,211 & Valid \\
\hline 2 & Butir Pernyataan 2 & 0,614 & 0,211 & Valid \\
\hline 3 & Butir Pernyataan 3 & 0,505 & 0,211 & Valid \\
\hline 4 & Butir Pernyataan 4 & 0,697 & 0,211 & Valid \\
\hline 5 & Butir Pernyataan 5 & 0,586 & 0,211 & Valid \\
\hline 6 & Butir Pernyataan 6 & 0,719 & 0,211 & Valid \\
\hline 7 & Butir Pernyataan 7 & 0,398 & 0,211 & Valid \\
\hline 8 & Butir Pernyataan 8 & 0,505 & 0,211 & Valid \\
\hline 9 & Butir Pernyataan 9 & 0,697 & 0,211 & Valid \\
\hline 10 & Butir Pernyataan 10 & 0,586 & 0,211 & Valid \\
\hline \multicolumn{5}{|c|}{ Kinerja Karyawan } \\
\hline 1 & Butir Pernyataan 1 & 0,759 & 0,211 & Valid \\
\hline 2 & Butir Pernyataan 2 & 0,632 & 0,211 & Valid \\
\hline 3 & Butir Pernyataan 3 & 0,661 & 0,211 & Valid \\
\hline 4 & Butir Pernyataan 4 & 0,633 & 0,211 & Valid \\
\hline 5 & Butir Pernyataan 5 & 0,473 & 0,211 & Valid \\
\hline 6 & Butir Pernyataan 6 & 0,714 & 0,211 & Valid \\
\hline 7 & Butir Pernyataan 7 & 0,600 & 0,211 & Valid \\
\hline 8 & Butir Pernyataan 8 & 0,490 & 0,211 & Valid \\
\hline 9 & Butir Pernyataan 9 & 0,360 & 0,211 & Valid \\
\hline 10 & Butir Pernyataan 10 & 0,661 & 0,211 & Valid \\
\hline
\end{tabular}

Sumber : Data diolah (2020)

Berdasarkan tabel diatas dapat dilihat bahwa semua butir pernyataan valid, dimana semua item-item pernyataan memiliki nilai corrected item total corrected item lebih besar dari 0,211 .

\section{Uji Reliabilitas}

Tabel 5. Hasil Uji Reliabilitas

\begin{tabular}{|c|c|c|}
\hline Variabel & Cronchbach's Alpha & Keterangan \\
\hline Lingkungan Kerja & 0,603 & Reliabilitas \\
\hline Motivasi & 0,787 & Reliabilitas \\
\hline Kinerja Karyawan & 0,777 & Reliabilitas \\
\hline
\end{tabular}

Sumber : Data diolah (2020) 
Dengan demikian, berdasarkan hasil perhitungan tabel diatas dapat dilihat bahwa nilai rca lebih besar dari 0,6 sehingga instrumen penelitian dikatakan reliabel.

\section{Uji Normalitas}

Tabel 6. Hasil Uji Normalitas

One-Sample Kolmogorov-Smirnov Test

\begin{tabular}{|ll|r|}
\hline & & $\begin{array}{c}\text { Unstandardized } \\
\text { Residual }\end{array}$ \\
\hline $\mathrm{N}$ & Mean & 60 \\
Normal Parameters ${ }^{\mathrm{a}, \mathrm{b}}$ & Std. Deviation & .0000000 \\
& Absolute & .17648463 \\
Most Extreme Differences & .085 \\
& Positive & .085 \\
& Negative & .082 \\
Test Statistic & & .085 \\
Asymp. Sig. (2-tailed) & & $.200^{\mathrm{c}, \mathrm{d}}$ \\
\hline
\end{tabular}

a. Test distribution is Normal.

b. Calculated from data.

c. Lilliefors Significance Correction.

$\mathrm{d}$. This is a lower bound of the true significance.

Sumber : Data diolah (2020)

Berdasarkan tabel diatas maka dapat dilihat nilai Asymp. Sig (2-Tailed) yaitu 0,304 sehingga lebih besar dari 0,05 atau $0,200>0,05$, maka data pada penelitian ini berdistribusi normal.

\section{Uji Multikolinearitas}

Tabel 7. Uji multikolinearitas Coefficients $^{\mathbf{a}}$

\begin{tabular}{|c|c|c|}
\hline \multirow{2}{*}{ Model } & \multicolumn{2}{|c|}{ Collinearity Statistics } \\
\hline & Tolerance & VIF \\
\hline Lingkungan Kerja & .734 & 1.362 \\
\hline Motivasi & .734 & 1.362 \\
\hline
\end{tabular}

a. Dependent Variable: Kinerja Karyawan

Sumber : Data diolah (2020)

Pada tabel diatas, memperlihatkan bahwa nilai Variance Inflation factor (VIF) untuk variabel Lingkungan Kerja (X1) diperoleh sebesar 1,362 dan Motivasi (X2) diperoleh sebesar 1,362 dimana masing-masing nilai tolerance variabel bebas kurang dari 1 dan nilai VIF kurang dari 10, dengan demikian model regresi tidak terjadi korelasi antar variabel independent didalam persamaan itu sendiri atau tidak ada multikolinearitas.

\section{Uji Autokorelasi}

Tabel 8. Uji Autokorelasi

Model Summaryb

\begin{tabular}{|c|c|c|c|c|c|}
\hline Model & $\mathrm{R}$ & $\begin{array}{c}\mathrm{R} \\
\text { Square }\end{array}$ & $\begin{array}{c}\text { Adjusted R } \\
\text { Square }\end{array}$ & $\begin{array}{c}\text { Std. Error of } \\
\text { the Estimate }\end{array}$ & $\begin{array}{c}\text { Durbin- } \\
\text { Watson }\end{array}$ \\
\hline 1 & $.859 \mathrm{a}$ & .738 & .729 & 2.214 & 1.215 \\
\hline
\end{tabular}

a. Predictors: (Constant), Motivasi, Lingkungan Kerja

b. Dependent Variable: Kinerja Karyawan

Sumber : Data diolah (2020)

Dari tabel diatas, diperoleh nilai Durbin - Watson sebesar 1.215 dan berada diantara $(1,1-1,54)$ sesuai dengan ketentuan maka model regresi ini tanpa kesimpulan. 


\section{Uji Heteroskedastisitas}

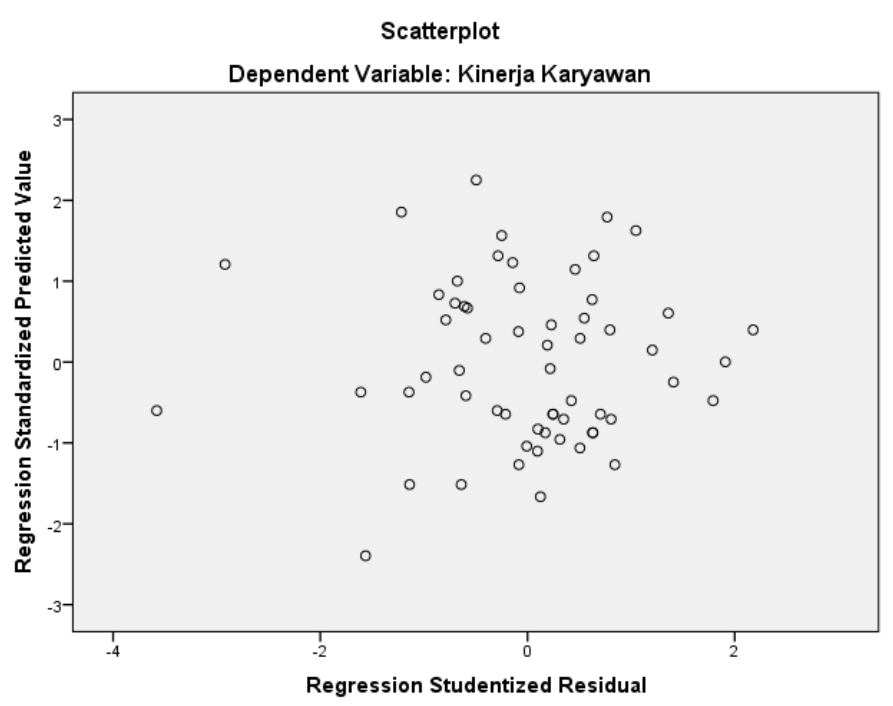

Gambar 2. Heteroskedastisitas

Pada gambar diatas, dapat dilihat bahwa titik-titik pada grafik scatter plot mempunyai pola penyebaran yang jelas dan titik-titik tersebut menyebar diatas dan dibawah angka 0 pada sumbu Y, dengan demikian hal ini menunjukkan bahwa tidak terjadi heterokedaktisitas.

\section{Analisis Regresi Linier Sederhana}

Tabel 9. Regresi Sederhana Variabel Lingkungan Kerja

\section{Coefficients ${ }^{\mathbf{a}}$}

\begin{tabular}{|c|l|r|r|r|r|r|}
\hline \multirow{2}{*}{\multicolumn{2}{|c|}{ Model }} & \multicolumn{2}{|c|}{$\begin{array}{c}\text { Unstandardized } \\
\text { Coefficients }\end{array}$} & $\begin{array}{c}\text { Standardized } \\
\text { Coefficients }\end{array}$ & \multirow{2}{*}{$\mathrm{t}$} & \multirow{2}{*}{ Sig. } \\
\cline { 3 - 5 } \multicolumn{2}{|c|}{} & \multicolumn{1}{|c|}{ B } & Std. Error & \multicolumn{1}{c|}{ Beta } & & \\
\hline \multirow{2}{*}{1} & (Constant) & -1.248 & 3.781 & & -.330 & .743 \\
\cline { 2 - 5 } & Lingkungan Kerja & 1.009 & .090 & .826 & 11.163 & .000 \\
\hline
\end{tabular}

a. Dependent Variable: Kinerja Karyawan

Sumber : Data diolah (2020)

Berdasarkan hasil perhitungan tersebut maka dapat diperoleh persamaan regresi linear sederhana sebagai berikut : $\mathrm{Y}=-1.248+1.009 \mathrm{X}_{1}$. Artinya nilai (a) atau konstanta sebesar -1.248 nilai ini menunjukkan bahwa pada saat lingkungan kerja $\left(\mathrm{X}_{1}\right)$ bernilai 0 atau tidak meningkat, maka kinerja karyawan (Y) akan tetap bernilai -1.248 koefisien regresi nilai (b) sebesar 1.009 (positif) yaitu menunjukkan pengaruh yang searah yang artinya jika Lingkungan kerja ditingkatkan sebagai sebesar satu-satuan maka akan meningkatkan kinerja karyawan sebesar 1.009 satuan.

Tabel 10. Regresi Sederhana Variabel Motivasi

Coefficientsa

\begin{tabular}{|c|l|r|r|r|r|r|}
\hline \multirow{2}{*}{ Model } & \multicolumn{2}{|c|}{$\begin{array}{c}\text { Unstandardized } \\
\text { Coefficients }\end{array}$} & $\begin{array}{l}\text { Standardized } \\
\text { Coefficients }\end{array}$ & \multirow{2}{*}{$\mathrm{t}$} & \multirow{2}{*}{ Sig. } \\
\cline { 3 - 7 } \multicolumn{2}{|c|}{} & \multicolumn{1}{|c|}{ B } & Std. Error & \multicolumn{1}{|c|}{ Beta } & & \\
\hline \multirow{2}{*}{1} & (Constant) & 10.800 & 4.904 & & 2.202 & .032 \\
\cline { 2 - 7 } & Motivasi & .696 & .113 & .628 & 6.145 & .000 \\
\hline
\end{tabular}

a. Dependent Variable: Kinerja Karyawan

Sumber : Data diolah (2020) 
Berdasarkan hasil perhitungan tersebut maka dapat diperoleh persamaan regresi linear sederhana sebagai berikut: $\mathrm{Y}=10.800+0.696 \mathrm{X}_{2}$. Artinya nilai (a) atau konstanta sebesar 10.800 nilai ini menunjukkan bahwa pada saat motivasi (X2) bernilai 0 atau tidak meningkat, maka kinerja karyawan (Y) akan tetap bernilai 10.800 koefisien regresi nilai (b) sebesar 0.696 (positif) yaitu menunjukkan pengaruh yang searah yang artinya jika motivasi ditingkatkan sebagai sebesar satu-satuan maka akan meningkatkan kinerja karyawan sebesar 0.696 satuan.

\section{Analisis regresi linier berganda}

\section{Tabel 11. Hasil analisis regresi linier berganda} Coefficients ${ }^{\mathbf{a}}$

\begin{tabular}{|c|l|r|r|r|r|r|}
\hline \multicolumn{2}{|c|}{ Model } & \multicolumn{2}{|c|}{$\begin{array}{c}\text { Unstandardized } \\
\text { Coefficients }\end{array}$} & $\begin{array}{c}\text { Standardized } \\
\text { Coefficients }\end{array}$ & \multirow{2}{*}{$\mathrm{t}$} & \multirow{2}{*}{ Sig. } \\
\cline { 3 - 5 } \multicolumn{2}{|c|}{} & \multicolumn{1}{|c|}{ B } & Std. Error & \multicolumn{1}{c|}{ Beta } & & \\
\hline \multirow{3}{*}{1} & (Constant) & -7.182 & 3.861 & & -1.860 & .068 \\
\cline { 2 - 7 } & Lingkungan Kerja & .836 & .097 & .684 & 8.649 & .000 \\
\cline { 2 - 7 } & Motivasi & .305 & .088 & .275 & 3.480 & .001 \\
\hline
\end{tabular}

a. Dependent Variable: Kinerja Karyawan

Sumber : Data diolah (2020)

Dari tabel diatas diperoleh persamaan regresi berganda berikut:

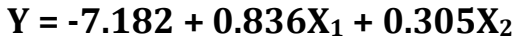

1) Nilai konstanta sebesar $-7,182$ menyatakan bahwa jika nilai variabel Lingkungan Kerja (X1) dan Motivasi (X2) tidak ada atau = 0, maka nilai kinerja adalah sebesar -7,182.

2) Koefisien korelasi variabel Lingkungan Kerja (X1) 0,836, mengandung arti bahwa setiap penambahan 1 (satu) poin variabel lingkungan kerja, maka hal itu meningkatkan kinerja sebesar 0,836 kali.

3) Koefisien korelasi variabel Motivasi (X2) 0,305, mengandung arti bahwa setiap penambahan 1 (satu) poin variabel motivasi, maka hal itu akan meningkatkan kinerja sebesar 0,305 kali.

\section{Koefisien Determinasi}

Tabel 12. Hasil Koefisien Determinasi Model Summaryb

\begin{tabular}{|c|c|c|c|c|}
\hline Model & $\mathrm{R}$ & $\mathrm{R}$ Square & $\begin{array}{c}\text { Adjusted R } \\
\text { Square }\end{array}$ & $\begin{array}{c}\text { Std. Error of the } \\
\text { Estimate }\end{array}$ \\
\hline 1 & $.859 \mathrm{a}$ & .738 & .729 & 2.214 \\
\hline
\end{tabular}

a. Predictors: (Constant), Motivasi, Lingkungan Kerja

b. Dependent Variable: Kinerja Karyawan

Sumber : Data diolah (2020)

Berdasarkan perhitungan pada tabel diatas, diperoleh nilai koefisien determinasi ( $\mathrm{R}$ Square) sebesar 0,738, maka dapat disimpulkan bahwa Lingkungan Kerja (X1) dan Motivasi (X2) secara bersama-sama memiliki konstribusi pengaruh sebesar 73,8\% terhadap Kinerja Karyawan (Y), sisa nya $26,2 \%$ dipengaruhi oleh factor lain yang tidak diteliti.

\section{Uji Hipotesis}

Untuk pengujian pengaruh antara variabel Lingkungan Kerja (X1) dan Motivasi (X2) terhadap Kinerja Karyawan (Y) dapat dilakukan dengan uji statistik t (uji secara parsial). Dalam penelitian ini digunakan kriteria signifikan 5\% $(0,05)$ dengan membandingkan dengan yaitu sebagai berikut:

1) Jika t hitung $<$ t tabel : berarti diterima ditolak $(\alpha=5 \%)$

2) Jika t hitung $>$ t tabel : berarti ditolak diterima $(\alpha=5 \%)$ 
Tabel 13. Hasil Uji t Lingkungan Kerja

Coefficients ${ }^{\mathbf{a}}$

\begin{tabular}{|l|l|r|r|r|r|r|}
\hline \multicolumn{2}{|c|}{ Model } & \multicolumn{2}{|c|}{$\begin{array}{c}\text { Unstandardized } \\
\text { Coefficients }\end{array}$} & $\begin{array}{c}\text { Standardized } \\
\text { Coefficients }\end{array}$ & \multirow{2}{*}{$\mathrm{t}$} & \multirow{2}{*}{ Sig. } \\
\cline { 3 - 5 } \multicolumn{2}{|c|}{} & \multicolumn{1}{|c|}{ B } & Std. Error & \multicolumn{1}{c|}{ Beta } & & \\
\hline \multirow{2}{*}{1} & (Constant) & -1.248 & 3.781 & & -.330 & .743 \\
\cline { 2 - 5 } & Lingkungan Kerja & 1.009 & .090 & .826 & 11.163 & .000 \\
\hline
\end{tabular}

a. Dependent Variable: Kinerja Karyawan

Sumber : Data diolah (2020)

Dari tabel diatas diperoleh nilai $t$ hitung $>t$ tabel $(11.163>1,672)$ dari nilai signifikan $0,000<0,005$ maka dapat disimpulkan $H^{a_{1}}$ diterima atau variabel Lingkungan Kerja (X1) secara parsial berpengaruh positif dan signifikan terhadap Kinerja Karyawan (Y).

Tabel 14. Hasil Uji t Motivasi

Coefficients $^{\mathrm{a}}$

\begin{tabular}{|c|l|r|r|r|r|r|}
\hline \multirow{2}{*}{ Model } & \multicolumn{2}{|c|}{$\begin{array}{c}\text { Unstandardized } \\
\text { Coefficients }\end{array}$} & $\begin{array}{c}\text { Standardized } \\
\text { Coefficients }\end{array}$ & \multirow{2}{*}{$\mathrm{t}$} & \multirow{2}{*}{ Sig. } \\
\cline { 3 - 5 } & \multicolumn{1}{|c|}{ B } & Std. Error & \multicolumn{1}{|c|}{ Beta } & & \\
\hline \multirow{2}{*}{1} & (Constant) & 10.800 & 4.904 & & 2.202 & .032 \\
\cline { 2 - 7 } & Motivasi & .696 & .113 & .628 & 6.145 & .000 \\
\hline
\end{tabular}

a. Dependent Variable: Kinerja Karyawan

Sumber : Data diolah (2020)

Dari tabel diatas, diperoleh nilai $t$ hitung $>t$ tabel $(6,145>1,672)$ dari nilai signifikan $0,000<0,05$ maka dapat disimpulkan $\mathrm{H}^{a_{2}}$ diterima atau variabel Motivasi (X2) secara parsial berpengaruh positif dan signifikan terhadap Kinerja Karyawan $(\mathrm{Y})$.

Tabel 15. Hasil Uji F

ANOVAa $^{\mathrm{a}}$

\begin{tabular}{|c|c|c|c|c|c|c|}
\hline \multicolumn{2}{|c|}{ Model } & $\begin{array}{l}\text { Sum of } \\
\text { Squares }\end{array}$ & $\mathrm{df}$ & $\begin{array}{l}\text { Mean } \\
\text { Square }\end{array}$ & $\mathrm{F}$ & Sig. \\
\hline \multirow{3}{*}{1} & Regression & 787.495 & 2 & 393.748 & 80.303 & $.000^{\mathrm{b}}$ \\
\hline & Residual & 279.488 & 57 & 4.903 & & \\
\hline & Total & 1066.983 & 59 & & & \\
\hline
\end{tabular}

a. Dependent Variable: Kinerja Karyawan

b. Predictors: (Constant), Motivasi , Lingkungan Kerja

Sumber : Data diolah (2020)

Dari tabel diatas diperoleh $\mathrm{F}$ hitung $=80,303>2,766$ atau ( $\mathrm{F}$ hitung $>\mathrm{F}$ tabel) sehingga $\mathrm{HO}$ ditolak dan Ha diterima. Artinya terdapat pengaruh positif dan simultan antara Lingkungan Kerja dan Motivasi Terhadap Kinerja Karyawan.

\section{Kesimpulan}

Secara simultan variabel Lingkungan kerja $\left(\mathrm{X}_{1}\right)$ dan motivasi $\left(\mathrm{X}_{2}\right)$ terhadap kinerja karyawan $(\mathrm{Y})$ berpengaruh sangat kuat, positif dan signifikan secara bersama-sama dengan $\mathrm{f}$ hitung 80,303 $>\mathrm{f}_{\text {tabel }}(2,766)$ dan signifikansi lebih kecil dari 5\% $(0,000<0,05)$. Diperoleh hasil uji persamaan regresi : $Y=-7,182+0,836 \mathrm{X} 1+0,305 \mathrm{X}$. Nilai $\mathrm{R}$ (korelasi) adalah 0,859 dan nilai R Square (determinasi) 0,738, menunjukkan bahwa variabel $\mathrm{X}_{1}$ (Lingkungan Kerja) dan $\mathrm{X}_{2}$ (Motivasi) terhadap Y (Kinerja Karyawan) sebesar 73,8\% dan sisanya sebesar 26,2\% dipengaruhi oleh faktor-faktor lain yang tidak diteliti. 


\section{Daftar Pustaka}

Alex S, Nitisemito. (2013). Wawasan Sumber Daya Manusia. Jakarta: Pustaka Utama Grafiti.

Alghifari. (2010). Analisis Regresi Teori, Kasus dan Solusi. Edisi kedua. Yogyakarta : BPFE.

Anoraga, Panji. (2013). Psikologi Kerja. Jakarta : Rineka Cipta.

Arikunto, Suharsimi. (2012). Prosedur Penelitian. Jakarta: Rineka Cipta

Dessler, Gary. (2015). Manajemen Sumber Daya Manusia, Jakarta : Salemba Empat

Ghozali, Imam. (2013). Aplikasi Analisis Multivariete dengan Program IBM SPSS 23 (Edisi 8). Semarang: Badan Penerbit Universitas Dipenegoro .

Gracia, Bunga, Astra. (2019). Pengaruh Motivasi dan Lingkungan Kerja terhadap Kinerja Karyawan Pada PT. Triview Geospital Mandiri Jakarta Selatan. Jurnal JIMF 2(2), 31 - 48

Handayani, Rima. \& Via Solihah. (2020). Pengaruh Disiplin Kerja dan Suasana Kerja Terhadap Kinerja Karyawan pada PT.Gunung Agung Tangerang Selatan. Jurnal Jenius 3 (2).

Handoko. (2013). Manajemen : Edisi kedua, Cetakan Ketigabelas. Yogyakarta : BPFE.

Hasibuan, Malayu S.P. (2016). Manajemen Sumber Daya Manusia. Edisi Revisi. Jakarta: Penerbit PT Bumi Aksara.

Kasenda, Ririvega. (2013). Kompensasi dan Motivasi Pengaruhnya Terhadap Kinerja Karyawan Pada PT.Bangun Wenang Beverages Company Manado. Jurnal Emba.Volume 1. Nomor 3. Hal 853-859.

Mamesah, Andrew M.C., Lotje Kawet., Victor P.K Lengkong. (2016). Pengaruh Lingkungan Kerja, Disilin Kerja, dan Loyalitas Kerja Terhadap Kinerja Karyawan Pada LPP RRI Manado. Jurnal EMBA. ISSN: 600-611, 4 (3).

Mangkunegara, Anwar, Prabu. (2015). Manajemen Sumber Daya Manusia. Perusahaan.Bandung : Remaja Rosdakarya.

Mulyadi. (2015) . Manajemen Sumber Daya Manusia. Bogor: IN MEDIA.

Rivai, Zainal, Veithzal. (2015). Manajemen Sumber Daya Manusia untuk Perusahaan dari Teori ke Praktik, Jakarta:PT Raja Grafindo Persada.

Santoso, Singgih. (2011). Structural Equation Modeling, Edisi 1, PT Elex Media Komputindo, Jakarta.

Sartika, Dewi. (2018). Pengaruh Pendidikan Dan Pelatihan, Kompensasi Dan Motivasi Terhadap Kinerja Karyawan Pada Rumah Sakit Bhineka Bakti Husada Tangerang Selatan. Jurnal KREATIF. Vol 6, No. 4

Simamora, Henry. (2015). Manajemen Sumber Daya Manusia. Yogyakarta: STIEY

Sugiyono. (2012). Metode Penelitian Pendidikan Kuantitatif, Kualitatif dan R\&D.Bandung : Alfabeta.

. (2013). Metode Penelitian Kuantitatif, Kualitatif dan R\&D. Bandung : Alfabeta.

. (2015). Metode Penelitian Pendidikan Kuantitatif, Kualitatif dan R\&D.

Bandung : Alfabeta.

. (2016). Metode Penelitian Pendidikan Pendekatan Kuantitatif, Kualitatif dan R\&D. Bandung : Alfabeta.

Sunyoto, Danang. (2015). Teori Perilaku Keorganisasian. Jakarta: PT Buku Seru.

Supangat, Andi. (2010). Statistik Dalam Kajian Deskriptif, Inferensi, dan Nonparametrik. Jakarta: Kencana Prenada Media Group. 
Suryani, N. Lilis. (2019). Pengaruh Kompensasi Dan Lingkungan Kerja Terhadap Kinerja Karyawan PT. Indo Tekhnoplus. Jurnal JENIUS. Vol. 2, No. 2

Sedarmayanti. (2011). Manajemen Sumber Daya Manusia. Reformasi Birokrasi dan Manajemen Pegawai Negeri Sipil, Cetakan Kelima, PT Refika Aditama, Bandung.

Terry, George, R. \& Leslie W, Rue. (2011). Dasar-Dasar Manajemen. Jakarta : Bumi Aksara.

Wibowo. (2016). Manajemen Kinerja. Jakarta : PT. Rajagrafindo Persada

Widowati. (2020). Analisis Pengaruh Kepemimpinan, Lingkungan Kerja dan Motivasi Kerja Terhadap Produktivitas Kerja Karyawan pada PT. Mustika Citra Rasa. Jurnal JIMF 3 (3) Hal $296-303$ 